\title{
THE HELLENISTIC CONNECTION TO JEWISH BELIEFS ABOUT ANGELS ${ }^{1}$
}

\author{
Annette Evans \\ Research Fellow \\ University of the Free State
}

\begin{abstract}
This article is part 2 of a preceding one ${ }^{2}$ which suggested that Jewish beliefs about the functioning of angels originated in two threads: the unique ancient Egyptian institution of the king as the divine son of God (which includes solar worship), and the concept of the Divine Council, in which the supreme God is the king of the gods. The method of investigation involved a close reading of texts (c. 600BCE to c. 200CE) displaying marked angelological content, combined with a History of Religions methodology. Certain motifs, especially 'throne' and 'sun/fire', which were identified as characteristic of angelic functioning, were compared across a broad spectrum of texts. This article presents a similar examination of relevant texts written after the onset of Hellenism, and suggests that the intellectual abstractions of Hellenism facilitated the transition to the reception of the concept of Christ as the divine Son of God within a monotheistic framework.
\end{abstract}

Key Words: Angels; Jewish; Hellenism; Philo; Christianity

\section{Introduction}

What, therefore, has Jerusalem to do with Athens? The answer, in our context, is that Alexandria has to do with them both (Runia 1986:4).

The onset of Hellenism is usually identified with Alexander the Great, but its influence continued far beyond the subsequent Roman rule. ${ }^{3}$ Hellenistic philosophy stimulated new ways of thinking about mediation between God and mankind. To some extent the fulcrum on which Jewish angelology was enabled to facilitate the reception of Christianity is perceptible in the writings of the Jewish scholar Philo of Alexandria. ${ }^{4}$

\footnotetext{
This material is based upon work supported financially by the National Research Foundation. The article is based on the second half of my unpublished dissertation (Evans 2007).

"The Origins of Jewish Beliefs in Angels" Scriptura 101 (2009:198-205).

Alexander identified with the traditional Egyptian concept of the ruling pharaoh as being a god-king. The Egyptians wanted a native Pharaoh to continue the divine kingship, but the Alexandrians maintained a cult of an anthropomorphic goddess known as Agatha Tyche (good fortune) ..."merely a kind of ambivalent halfway house between monotheistic thinking and the old divinely ordered cosmos" (Eddy 1961:336). Eddy reports "a growing craving for some redemptive religion" - a yearning for a Messiah, a God who would appear miraculously for the salvation of his people, but during the early years of Hellenism it was actually the overwhelming impact of the hellenised ancient Egyptian goddess Isis (largely disseminated by sailors) which became the central divine figure of a world religion (Evans 1999:30).

4 Plato's student Xenocrates (head of the Alexandrian Academy from 338 to 314 BCE) visualized a three-fold composition of mankind: intellect, soul and body, in the hierarchical relation of 'god-daemon-man'. The 'daemons' are explained in Timaeus 42D ff. as intermediaries - halfway between gods and humans, linking both groups. Philo uses the terms daimones and angeloi more or less as synonyms (Evans 2007a:169-171).
} 


\section{Philo of Alexandria (ca.20 BCE - ca.50 CE)}

Olyan (1993:11) observed that "Exegesis is at least a major aspect, if not the most significant component, of the elusive framework sought by scholars in order better to understand the development of ideas about angels in late biblical and post-biblical texts." In Philo's exegesis of Gen 1:26,27, 2:7 and 6:1-4 characteristic motifs of Jewish angelology such as God's throne in heaven disappear, ${ }^{5}$ and the mechanism of mediation between God and man is seen from a hellenistic orientation. In his exegesis of v. 27, "So God created man in his own image; in the image of God he created him; male and female he created them", Philo interprets the image ( $\dot{\eta}$ cik $\dot{\omega} v$ ) to mean the soul's director or intellect, and it is this specific aspect in which humankind stands in an image relation to God (Runia 2001:235):

The term, image, has been used here with regard to the director of the soul, the intellect ... For it would seem that the same position that the Great director holds in the entire cosmos is held by the human intellect in the human being (Opif. 69, trans. Runia 2001:64).

Philo's exegesis of Gen 2:7 (Opif. 134) reinforces this idea, and complements his exegesis of Gen 1:26,27:
After this he [Moses] says that God $(\theta \varepsilon$ cós) moulded the human being, taking clay from the earth, and he inbreathed onto his face the breath of life [Gen 2:7]. By means of this text too he shows us in the clearest fashion that there is a vast difference between the human being who has been moulded now [Gen 2:7] and the one who previously came into being after the image of God. For the human being who has been moulded as sense- perceptible object [Gen 2:7] already participates in quality, consists of body and soul, is either man or woman, and is by nature mortal. The human being after the image is a kind

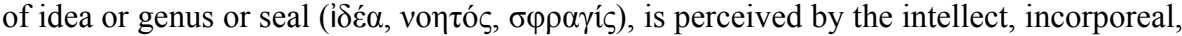 neither male nor female and is immortal by nature (trans. Runia 2001:82).

Pearson (1984:325) summarises as follows: "The former is an ideal type while the latter is empirical man, consisting of both mortal and immortal parts". Opif. 139 confirms Philo's understanding of the human intellect/mind (áv $\theta \rho \omega ́ \pi ı v o \varsigma$ voûs), as mankind's portion of the divine Logos: "the human being has come into existence as its [the Logos's] likeness and representation by being inbreathed into the face (Gen 2:7), which is the location of the

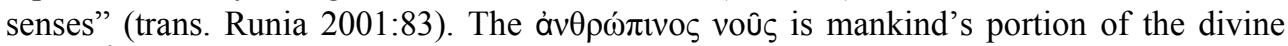
Logos. $^{6}$

The concept of a human being as standing on the borderline between mortal and immortal nature, is the crucial idea in the contribution of Jewish angelology to Christianity. ${ }^{7}$ Philo uses the term $\mu \varepsilon \theta$ ópros to unify the two accounts of the creation of man:

\footnotetext{
5 Angelological motifs were identified after careful reading of certain texts discussed in Evans (2009b:199). The motifs, especially 'throne' and 'sun/fire' were identified as characteristic of descriptions of angelic functioning.

6 In Stoic circles the term 'Logos' was a link which connected the Absolute with the world and humanity. The term became widespread because of the desire to conceive of God as transcendent and yet immanent at the same time (Goodenough 1969:139).

7 Carrell $(1997: 110,111)$ points out that the concept of the Logos enabled transformation in the sense that the self-revelation of God could be manifested in the form of an angel. Going further, Hannah (1999:217) sees the influence of Philo's Logos doctrine in that whereas the Logos is the agent of creation, it is also the image of God and his firstborn son. (This is not to say that Jesus was understood to be an angel, although he was sometimes conceived to be like an angel in function, and occasionally recognised as having temporarily taken up the form of an angel, i.e. appeared as 'angelomorphic').
} 
...the sense-perceptible and individual human being has a structure which is composed of earthly substance and divine spirit, for the body came into being when the Craftsman took clay and moulded [Gen 2:7] a human shape out of it, whereas the soul obtained its origin from nothing which has come into existence at all, but from the Father and Director of all things. What he breathed in was nothing else than the divine spirit [Gen 2:7] which has emigrated here from that blessed and flourishing nature for the assistance of our kind, in order that, even if it is mortal with regard to its visible part, at least with regard to its invisible part it would be immortalized. For this reason it would be correct to say that the human being stands on the borderline between mortal and immortal nature

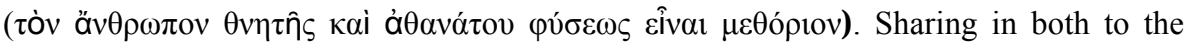
extent necessary, he has come into existence as a creature which is mortal and at the same time immortal, mortal in respect of the body, immortal in respect of the mind (Opif. 135, trans. Runia 2001:82).

Thus the term $\mu \varepsilon \theta$ ópros provides the foundation of the idea of the potential for human access to heaven, and explains Philo's understanding of why the human intellect/mind yearns to ascend to heaven to be reunited with that of God.

Van Huyssteen (2006:121) sees the description in Gen 1:26-27 as defining the relationship between humanity and deity. The primal human created here "is therefore revealed as a mediating or intermediary figure standing between the human and divine realms". He notes that the primal human "emerges here as a paradigm for intermediary figures in ancient Israelite society". Van Huyssteen refers only to Gen 1:26, 27, but it is notable that Philo sees Gen 2:7 as complementary to these verses, clinching the concept of the imparting of immortality to the earthly, created man. ${ }^{8}$ Thus the crucial link between the Judaism of Philo's lifetime and Christianity is provided by the concept that by the inbreathing of God's spirit, mankind has been provided with the quality necessary for access to heaven $\mu \varepsilon \theta$ ó $\rho 10 \varsigma$, i.e. the potential for deification.

Bousset (1913:389) explains the idea of the connection of the transcendent God with the world and humanity by means of the concept of a hypostasis: he perceives this to occur where the "monotheistic idea struggles free from the older polytheism". The monotheistic tendency 'volatises' originally concrete figures of deities into abstract figures which are half person and half qualities of God, to satisfy the quest for a transcendent, purely spiritual interpretation of God. ${ }^{9}$

By taking 'Let us make' as plural (Opif. 72), he has been interpreted to suggest that 'collaborators' assisted the demiurgos in creating man's 'lower soul' (Gen 2:7) and that this is the source of evil as opposed to the spirit of God who is all good, and whose spirit was breathed into mankind, providing the animation which the ‘collaborators' could not achieve. Philo's explanation for why mankind participates in both good and evil conforms to his concept of mankind as made up of a 'mixed nature', divine and human. Philo's understanding of the divine nature in man 'longing' to be re-united with God, is illustrated in his allegorical exegesis of Abraham's sacrifice of Isaac (Gen 22:6) in Cher. 27-28,31, where he transforms a Jewish Biblical text into an abstract conception of heavenly ascent. To Philo the ultimate meaning and goal of ascent is to sever the mortal element and "fly upward to God with his understanding stripped of its trammels". Goodenough (1969:7-8) suggests that by Philo's time Jews had taken over the Pythagorean Platonism of Alexandria in terms of ascent of the soul in order to be reunited with God, and this necessitates severance from the 'sensible' or irrational life.

9 Philo's platonically orientated exegesis of the 'flaming sword' ('fire and knife') which "severs the 'mortal element' away from himself, thus to fly upward to God with his understanding stripped of its trammels" supplies a hint which helps to make sense of the supreme 'once for all' sacrifice of the Son of God/Son of Man. In his exegesis in Cher. 31 of the 'fire and knife' (see chapter 5) Philo explains that the cherubim are 


\section{Gnosticism, the Chaldean Oracles, and Corpus Hermeticum}

Three other angelological vectors which developed in the same hellenistic cultural context in which Philo worked, and which interacted with Jewish angelology, viz. Gnosticism, Hermeticism and the Chaldean Oracles, demonstrate the complexity of ideas during this syncretistic historical period. ${ }^{10}$ In The Apocryphon of John the notion of "two powers in heaven' is generally seen as rebellion by Jewish Gnostics against the biblical Creator. The motif of 'throne' appears in a negative light. This in itself seems to be a telling symptom of rebellion against ultimate authority, which in the Apocryphon of John is symbolized by the throne motif. Pearson (1997:120) suggests that the authors of the early Gnostic texts were "disaffected Jewish intellectuals open to the various religious and philosophical currents of Hellenistic syncretism". MacRae (1972:97) saw them as religious intellectuals who had suffered a "loss of confidence in the created world".

In the Neoplatonic Chaldean Oracles the Jewish idea of the function of angels as servants of God is combined with the concept of heavenly flight as the solution to the perceived gulf between humans and God. The Chaldean Oracles describe a system of intermediaries (including 'Iynges') which Lewy (1978:14n. 32,162) has demonstrated is derived from or at least is similar to the Jewish concept of hierarchical tiers of angels surrounding the throne of God. The movement is so similar to that described in Ezekiel 1:14 that the possibility must be considered that there is a connection between the Iynges in the Chaldean Oracles and the underlying angelic activity of Ezekiel 1 and 10. For instance in Fragment 3 of the Chaldean Oracles the Iynges are described as "fiery bodies, of the nature of lightning ... regarded as messengers of the gods ... who swiftly hasten forth from the Father and back towards Him ... leaping in tireless revolution into the worlds at the mighty command of the Father, as the thoughts of the Supreme Being: thinking through circular motion" (Lewy 1978:133-134).

Lewy (1978:441) recognises that the Chaldean Oracles reflect a fusion of Platonism with mysticism and magic. The motif of sun/fire runs through Jewish angelology starting from Egyptian solar worship and retains its position as a central concept in the process of theurgy in the second century CE. ${ }^{11}$ Egyptian elements, for instance the sun as creator are clearly evident in the Corpus Hermeticum, but the absence of the throne motif confirms its abstract, Platonic orientation. The Corpus Hermeticum texts demonstrate how, as part of the apperceptive mass ${ }^{12}$ of the authors, certain ancient angelological elements were incorporated into a new synthesis. According to Hermeticism salvation is necessary

symbols of God's two potencies: sovereignty and goodness, and the fiery sword is the symbol of reason, which unites them, "for it is through reason that God is both ruler and good."

10 For instance the 'Monad' is a Pythagorean term for the Highest God in Chaldean, Hermetic and Gnostic thought, and in each of these systems, the sole function of the Monad or First God or Father, is to 'think' the Platonic world of Ideas. Each of these three systems develops the concept of a Second God or Demiurgic Intellect which has a Dyadic nature, which actually begins the process of division which ultimately leads to creation and generation.

11 Frg. 3 (Psellus) describes the Father as fiery:

“... The Father snatched himself away, and did not enclose his own fire in his intellectual Power."

The term 'snatched himself away' underscores the ontological separation of the Father, who exists apart from everything (Majercik 1989:142). Frg. 121 from Proclus, affirms the importance of fire in this system:

"For the mortal who has approached the fire will possess the light from God."

12 "A group of present ideas, influential in determining what new ideas shall gain admission to consciousness and in what way new objects shall be perceived" (Corsini 2002:61). 
because mankind is subject to fate which is determined by the stars. ${ }^{13}$ In the Corpus Hermeticum the concept of the need for salvation in terms of heavenly ascent is the only aspect in which one can recognize an organic wholeness (see Cook 1997:41), but the following aspects also come strongly to the fore: all knowledge is obtained through revelation from God; a divine figure appears in response to prayer; an ethos of reverence for ultimate sovereignty; light (sun and fire) as a representation of God ("I am the light you saw, mind, your god," he said, "who existed before the watery nature that appeared out of darkness. The light-giving word who came from mind is the son of god", trans. Copenhaver 1992:2). In Poimandres' explanation to Hermes about "the way up - how it happens", the rationale behind 'deification' becomes clear:

They rise up to the father in order and surrender themselves to the powers, and, having become powers, they enter into god. This is the final good for those who have received knowledge: to be made god (Corpus Hermeticum 1.26 Copenhaver 1992:6).

The angelological significance of the Corpus Hermeticum lies in the concept of heavenly ascent as leading to deification in Neoplatonic terms. Deification in Corpus Hermeticum 13 entails the act of recognising god (Holzhausen 2004:849). In Corpus Hermeticum 1.7 Poimandres states "I wish to comprehend being and understand its nature and know god". This is essentially the goal of "heavenly ascent" which had been gathering momentum since the onset of Hellenism. ${ }^{14}$ The complexity and ambiguity of human potential for deification develops in this context of the search for an intellectual conception of salvation, but in Hermeticism it remained an elitist preoccupation.

\section{The Outcome of Jewish Angelology According to the Motifs: Early Christianity}

We have such a high priest, one who is seated at the right hand of the throne of the Majesty in heaven ... (Heb 8:1b).

And hath raised us up together, and made us sit together in heavenly places in Christ Jesus (Eph 2:6).

Rowland (1985:36) has pointed out that "the gap between early Christian theology and preChristian Jewish theology is not as wide as is sometimes asumed", and Van Huyssteen (2006) has observed that "the boundaries that separate tradition from its milieu are always exceedingly porous, although as theologians we often notoriously invent protective strategies that mask the necessary fluidity of traditions". In Christianity as seen in Hebrews and Revelation, angelic functioning also arises from the throne of God in heaven, ${ }^{15}$ is related to

13 See note 3.

14 In Corpus Hermeticum 1.26 this only takes place after death. In Protrepticus 1.8.4 Clement of Alexandria writes "The Word of God became man just that you may learn from a Man how it may be that man should become god." Malaty (1995:15,379) clarifies the difference between the concept of deification in the Corpus Hermeticum and that of the Alexandrian Fathers ("the grace of renewal'): "By deification the Alexandrians mean the renewal of human nature as a whole, to attain the characteristics of our Lord Jesus Christ in place of the corrupt human nature, so that the believer may enjoy partaking in the divine nature (2 Peter 1:4) or the new man in the image of His Creator" (Col. 3:10).

15 In the Osiris/Horus mythology the divine father/son relationship is expressed in an earthly coronation ritual. In the Letter to the Hebrews the resurrection of Christ is interpreted as an act of enthronement: the throne is a central metaphor for the new status of Christ, the Son of God, after his self-sacrifice, death and resurrection, and thus through the metaphor of the throne (Eskola 2001:205), the Son is actually identified as God himself. 
judgement, and is also intimately related to fire and sun (or light). ${ }^{16}$ Psalm 110, where Father and the Son both sit on the merkabah throne, surfaces throughout Hebrews (1:13; $5: 6 ; 8: 1 ; 10: 12,13 ; 12: 2)$. The following three verses from Psalm 110 provide clues to how it came about in a monotheistic context that Jesus could come to be viewed as equal to God and seated on God's throne in heaven. These ancient Egyptian analogies are used to express Christian understanding of the relation between Father and Son (Evans 2009a:141, 155). ${ }^{17}$

- "You are a priest forever after the order of Melchizedek" (Ps 110:4). Heb 5:6ff and 7:1ff refer to this verse. Psalm 110 reinforces the impression gained from Heb 7:1 that this Psalm deals with the enthronement of a king, but his status is derived from his role as high priest. This combination of the priestly function with that of the king can be traced back to ancient Egypt, where, by virtue of the institution of divine kingship the king was the only one qualified to perform the high priestly rituals. In Heb 7:17 the function of Jesus as mediator is combined with his unique role as high priest "after the order of Melchizedek" in the 'true tabernacle'. He becomes the deified, ultimate high priest, thus seated at the right hand of the throne of the Majesty in heaven.

- "Sit at my right hand until I make your enemies your footstool" (Ps 110:1b). This verse with its striking Egyptian connotations is referred to at Heb $1: 13 ; 8: 1 ; 10: 12,13 .{ }^{18}$

- "On holy mountains, from the womb of the rosy dawn, have I begotten you like the dew" (Psalm 110:3, trans. Kraus 1989:344). "The whole verse is a reference to the heavenly, divine origin of the king and should be understood accordingly" (Kraus 1989:350). In order for Jesus to be able to fulfill the high priestly function of sacrifice for sins, he has to have a divine as well as human origin. Just as in ancient Egyptian religion, so also in Hebrews, the combination of kingship with high priesthood necessitates divine Sonship. ${ }^{19}$

In the Book of Revelation various angelic figures undergo subtle shifts of identity in order to conform to the requirements of monotheism. ${ }^{20}$ Angelological motifs implying ascent to God's throne in heaven, i.e. the apocalyptic and early merkabah traditions, which are used in the beginning to describe Jesus, are eventually used at the end of the book to describe the divinity of the risen Christ. ${ }^{21}$ The puzzling ambiguity of Jewish angelology bears fruit in that

16 Heb 12:29 makes a surprising statement about the reverence and awe due to God, which harks back to the beginnings of merkabah themes in Ezekiel 1 and 10 in linking the heavenly throne to the major angelological motif of fire: "for our God is a consuming fire".

17 Hebrews must have been composed some time between 60 to 95 CE (Attridge 1992:97; Craddock 1998:8). The oldest extant manuscript of Hebrews is Egyptian, dating from about $200 \mathrm{CE}$, in which Hebrews is placed after Romans (Koester 2001:21).

18 See Hengel (1995:177) for an icongraphic example of Thutmosis IV (1422-1413 BCE) on his throne with his enemies as his footstool. In Matt 22:41-46 Jesus is reported as relating this concept to himself (cf. Eph 2:5,6).

19 The Egyptian pharaonic imagery is already introduced in Heb 1:8 with the allusion to 'the righteous scepter'. The Egyptian hieroglyph of the was-scepter of the pharaonic throne symbolises power and dominion (Wilkinson 1994:181). The association of Melchizedek as King of Justice reflects the Egyptian association of maintenance of Maat (approximately translateable in this context as justice tempered with mercy) with the occupant of the throne, and is in harmony with the observation that in Jewish texts the activity of judgement almost invariably accompanies any mention of the throne.

20 For example Michael represents Christ in the battle against evil (chaos) and in the end Christ is represented on God's throne by the sacrificial Lamb.

21 Rev 1:6b-7a ("coming with the clouds"); Rev 1:14 ("his head and his hair were white as white wool, white as snow; his eyes were like a flame of fire"), and Rev 2:16 ("Repent then. If not, I will come to you soon and war against them with the sword of my mouth"). 
for example the separate divine figures encountered in Daniel 7 and 10 are transformed into the Lamb sharing God's throne in the apocalyptic ending of Revelation. ${ }^{22}$ Thus Jesus as the sacrificial lamb is seen as one with God. The power of the conclusion is achieved by the build up of angelological themes throughout the book. The dramatic switch from the Jewish apocalyptic description of the throne of God in heaven, to the monotheistic worship of Jesus as the Lamb on the throne of God, is achieved through carefully structured subtle and ambiguous shifts in angelic identity. ${ }^{23}$ The subliminal impression of a deliberately structured indication of a shift in identity between Jesus and the major angelic figure is contributed to by an increase in intensity of imagery as the book unfolds. Just as John's tenses are 'constantly interfused' (Caird 1966:300), so an almost imperceptible shift takes place. For example the phrase in 22:16: "It is I, Jesus, who sent my angel to you ..." may be deliberately disguising the ploy of ambiguity, in that it harks back to Rev 1:1 which states, "The revelation of Jesus Christ, which God gave him ... and he made it known by sending his angel ...". This phase belongs to the first surface layer which blandly denies, but actually sets the stage for the ambiguity. In Rev 22:6b and 7a, the angel says "And the Lord, the God of the spirits of the prophets, has sent his angel to show his servants what must soon take place. And behold, I am coming soon." This again implies that Jesus is the angel who is lexicalised at Rev 21:9, but it could also imply that Jesus is "the Lord, the God of the spirits of the prophets". The question arises here, of who the "he" is who made it known, God or Jesus? The implication is that Jesus and God are one and the same figure (Evans 2007:255). Because Jesus is symbolised on the throne as a Lamb, Christ's sovereignty does not contradict monotheism, thus the 'fruitful' ambiguity of Jewish angelology (Ashton 1998:79) has served to make Christianity compatible with monotheism.

\section{Discussion}

The distribution of the throne motif in all the texts of this series of two articles indicates that Jewish angelology underwent a radical change during the first century CE (Evans 2008:443,462). Before the first century CE a form of anthropomorphism is present in the description of God's throne in heaven, but Philo's corpus reflects the effect of Hellenism on the traditional metaphor of the throne of God. The crucial transitional stage in Jewish angelology is perceptible in Philo's writings where the abstractions of Platonism come into play, and the throne metaphor is transformed into an abstract concept. Perhaps Christianity could continue the anthropomorphic concept of the throne in combination with the concept of 'Father', because Jesus, the Son of God, was incarnated as man.

Rowland (1982:103) points out that in the Book of Revelation, although Christ is not directly described as an angel, part of his role "is not too different from that of the angelic intermediaries", and Hannah's research (1999:215) confirms that the Book of Revelation, the Epistle to the Hebrews, and possibly the Gospel of Luke, all attribute to Christ roles or functions which traditionally belonged to principal angels (especially seen in the Michael traditions). In this regard Hannah (1999:217) sees the influence of Philo's Logos doctrine, where the Logos is the agent of creation, but also the image of God and his firstborn son. The concept of 'divine agents' may have provided early Jewish Christianity with a

22 For a brief review of scholarly discussion on these texts see Evans, 2007:159-165.

23 The shift in angelic identity is achieved through a complex interwoven pattern of lexicalization of angels. For more detail see Evans, 2007:248-255. 
conceptual framework into which to begin fitting the exalted Jesus, because they believed that Jesus had been given a position "at the right hand of God" (Eskola 2001:329). Deutsch (1999:157) points out that "Although Christianity suppressed or even attacked the belief in traditional Jewish mediator figures, it would have been impossible for early Christians to accept Jesus as a 'second God,' were it not for the precedent set by earlier Jewish angelic vice regent traditions". Bousset (1913:423) recognised that deification and sonship to God were understood by Irenaeus as synonymous concepts. ${ }^{24}$ The development of the concept of deification during the last centuries BCE seems to parallel the diachronic course of Jewish angelology, but the issue of monotheism is a complicating factor.

An aspect of the ambiguity of Jewish angelological texts is demonstrated by Hurtado (1988:21) who showed that the literature of post-exilic Judaism exhibits an interest in various figures who are described as holding a position next to God in honour and power, which we designate as 'divine agency'. These texts suggest that a degree of 'conceptual overlap' between God and an angelic emissary was already an aspect of Jewish exegesis prior to Christianity. ${ }^{25}$ Hurtado (1988:11) describes what he calls a 'Christological' merkabah tradition which occurs both in the Book of Revelation (e.g. Rev. 1:13ff) and in the Epistle to the Hebrews, where the resurrected Christ sits on the right hand of God on the throne, exalted to a position of heavenly rule above all angelic orders, and has titles appropriated to him which were originally applied to God as "a kind of binitarian reverence which included both God and the exalted Jesus". The vision of the risen Christ in Revelation, with all its allusions to the motifs which have angelological significance, confirms that the angelological motifs subsequently used for christological exposition were in existence long before the actual incarnation of Christ. This connection to the apocalyptic ending of the Book of Revelation $^{26}$ is perceptible in the goal of heavenly ascent stated in the merkabah scene in Heb 12:22-23:

But you have come to Mount Zion and to the city of the living God, the heavenly Jerusalem, and to innumerable angels in festal gathering, and to the assembly of the firstborn who are enrolled in heaven, and to a judge who is God of all, and to the spirits of just men made perfect.

The novelty of the above statement would not have been possible without the syncretistic contribution of each of the three cultural contexts of this discussion, Jewish, Egyptian and Greek.

\section{Conclusion}

In mythological terms the combination of Christ's humanity and his origin in the royal birth as divine Son of God is clearly understandable only against the background of the ancient

24 "Irenaeus speaks actually without embarrassment of the point that we men are to become Gods ... the Godlike Logos has become man so that man could become God's son, absorbing in himself the fullness of the deity (the Logos)" (Bousset 1913:423,424).

25 For example in Tobit 12:19-21 angelic ambiguity is expressly confronted when Raphael (alias Azariah), having revealed his true identity, says "Look, I am ascending to the One who sent me" (cf. Judg 13:20, John 16:5). The Divine Council association of the concept of instant angelic action in the sense of going out on a mission and returning, is also mentioned in one early version of Tobit.

26 "There shall no more be anything accursed, but the throne of God and of the Lamb shall be in it, and his servants shall worship him ... they need no light of lamp or sun, for the Lord God will be their light, and they shall reign for ever and ever" (Rev 22:3-5). 
Egyptian institution of divine kingship. The ancient Egyptian concept of the deification of the pharaoh (Horus) upon his enthronement as son of Osiris which was perpetuated through various mythological motifs in the syncretistic Hellenistic milieu may have played a vital role in the process of assimilation of deification to the concept of the Son of God. Tobin (1989:195) recognises that the Egyptian system of mytho-theology contained within itself "the possibility of producing a more abstract and intellectual ideal which was there for the comprehension of those who had the ability to perceive its inherent implications". The ubiquitous golden thread of the institution of Egyptian divine kingship runs through the history of the idea of intermediaries from the beginning to the end - disguised and hidden by ideology and counter-movement.

Even in Christianity, angelic functioning arises from the throne of God in heaven, is related to judgement, and intimately related to fire or sun (or light). The major angelological motifs of sun/fire and throne, which have appeared together in all the BCE texts dealt with in part 1 become separated in the Apocryphon of John, the Corpus Hermeticum and in the Chaldean Oracles. Seen synchronically, the bifurcation of the combination of throne and solar/fire motifs reflects a telling paradigm shift in thought about angels. The intellectual explanation in the Chaldean Oracles of the process of relaying communication between the 'Father' and mortals demonstrates how these primeval elements have been strained through the sieve of Platonism. When one considers Philo's analogy about the sun as a motif reflecting deity, it seems possible that Philo may have been part of the development towards the abstraction of the throne motif and of the transition of the sun motif to the fire associations of heavenly ascent. Philo's exegesis of Gen 1:26-27 and 2:7, and his concept of meqokioj seems to be a remarkable intellectual explanation of the angelic activity which, upon close reading, is already to be found in Ez 1:14 and Ezekiel 10, later in the Songs of the Sabbath Sacrifice, and in the Chaldean Oracles.

In terms of the diachronic development of the polytheistic aspects of angelology, a supreme monotheistic authority over polytheistic manifestations culminates in a resolution of polytheistic and 'magical' elements. The advent of Christianity forced a reconciliation between polytheism and monotheism - one that was unacceptable to the rabbis, but which made salvation available to all, not just to elite intellectuals. Ironically the new monotheism of Christianity can only be understood in terms of a nuanced view of ancient polytheistic ideas mediated through Jewish angelology. The Jewish genius was the result of the eclectic application of both Egyptian and hellenistic elements in their angelology. It was this seminal mixture in the syncretistic hellenistic context that mediated what in the first century CE was still largely a 'Jewish' Christianity. 


\section{BIBLIOGRAPHY}

Ashton, J 1994. Studying John: Approaches to the Fourth Gospel.

Oxford: Clarendon Press.

Attridge, HW1989. The Epistle to the Hebrews. A Commentary. Philadelphia: Fortress Press.

Bousset, W 1913. Kyrios Christos. Trans. J Steely 1970.

Göttingen: Vandenhoeck and Ruprecht.

Caird, GB 1966. A Commentary on the Revelation of St. John the Divine. London: Adam and Charles Black.

Cancik, H and Scheider, H (eds.) 2004. Brill's New Pauli. Leiden: Brill.

Carrell, PR 1997. Jesus and the Angels. Angelology and the Christology of the Apocalypse of John. Cambridge: Cambridge University Press.

Collins, JJ 2000. The Encyclopaedia of Apocalypticism. The Origins of Apocalypticism in Judaism and Christianity. New York: Continuum.

Copenhaver, BP 1992. Hermetica. Cambridge: Cambridge University Press.

Cook, J 1997. The Septuagint of Proverbs - Jewish and/or Hellenistic Proverbs?

Concerning the Hellenistic Colouring of LXX Proverbs. Leiden: EJ Brill.

Cook, J (ed.) 2009. Septuagint and Reception, Supplements to Vetus Testamentum 127. Leiden: Brill.

Corsini, RJ 2002. The Dictionary of Psychology. London: Brunner-Routledge.

Craddock, FB 1998. Hebrews. NIB, in Keck, LE et al. 1998. The New Interpreter's Bible. Nashville: Abingdon Press. 1-174.

Deutsch, N 1999. Guardians of the Gate. Leiden: Brill.

Eddy, SK 1961. The King is Dead. Studies in Near Eastern Resistance to Hellenism 334-31 BC. Lincoln: University of Nebraska Press.

Eskola, T 2001. Messiah and the Throne. Jewish Merkabah Mysticism and Early Christian Exaltation Discourse. Mohr Siebeck: Tübingen.

Evans, AHM 1999. Hellenism and the Formation of Coptic Identity: 332BCE-200CE.

A Coptic Trajectory through a Hellenistic Context. Unpublished MA thesis.

Evans, AHM 2007. The Development of Jewish Beliefs in Angels. Egyptian and Hellenistic Connections Ca 600 BCE-200 CE. Unpublished dissertation, University of Stellenbosch.

Evans, AHM 2008. Aspects of Ezekiel 1:14 in angelological texts found at Qumran. Journal for Semitics Vol 17, 2:443-464.

Evans, AHM 2009a. Ancient Egyptian Elements in Hebrews 1. in Cook, J (ed.) 2009. Septuagint and Reception, Supplements to Vetus Testamentum 127. Leiden: Brill.141-158.

Evans, AHM 2009b. The Origins of Jewish Beliefs in Angels (Part 1). Scriptura 101:198-215.

Goodenough, ER 1969. By Light Light. The Mystic Gospel of Hellenistic Judaism.

New Haven: Repr. Amsterdam. 
http://scriptura.journals.ac.za

The Hellenistic Connection to Jewish Beliefs about Angels

Haase, W 1984. Hellenistisches Judentum in römischer Zeit: 1. Halbband, Philon. Aufstieg und Niedergang des römischen Welt II Principat vol 21.1. Berlin/New York: De Gruyter.

Hannah, D 1999. Michael and Christ: Michael Traditions and Angel Christology in Early Christianity. Tübingen: Mohr Siebeck.

Hengel, M 1995. Studies in Early Christology. Edinburgh: T\&T Clark.

Holzhausen, J 2004. Corpus Hermeticum, in Cancik, H and Scheider, H (eds.) 2004. Brill's New Pauli. Leiden: Brill. 846-850.

Hurtado, LW 1988. One God, One Lord. Fortress: Philadelphia.

Keck, LE et al. 1998. The New Interpreter's Bible. Nashville: Abingdon Press.

Keel, O 1978. Yahwe-Visionen und Siegelkunst. Eine Neue Deutung der

Majesteitschilderungen in Jes 6, Ez 1 und 10 und Sach 4. Stuttgart: Verlag

Katholisches Bibelwerk. Koester, CR 2001. Hebrews. A New Translation with Introduction and Commentary.

The Anchor Bible. NY: Doubleday.

Kraus, HJ 1989. Psalms. Trans. HC Oswald. Minneapolis/Augsberg: Fortress.

Lewy, H 1978. Chaldean Oracles and Theurgy. Paris: Études Augustiniennes.

Mach, M 2000. From Apocalypticism to Early Jewish Mysticism? In Collins, JJ 2000. The Encyclopaedia of Apocalypticism. The Origins of Apocalypticism in Judaism and Christianity. New York: Continuum. 193-262.

MacRae, GW 1972. The Jewish Background of the Gnostic Sophia Myth. Nov. Test. 12:86100.

Majercik, R 1989. The Chaldean Oracles. EJ Brill: Leiden.

Malaty, Fr. TY 1995. The School of Alexandria. Book One. Before Origen. Jersey City, NJ: St. Mark's Coptic Orthodox Church.

Olyan, S 1993. A Thousand Thousands Served Him: Exegesis and the Naming of Angels in Ancient Judaism. Tübingen: Mohr Siebeck.

Pearson, BA 1984. Philo and Gnosticism, in Haase W 1984. Hellenistisches Judentum in römischer Zeit: 1. Halbband, Philon. Aufstieg und Niedergang des römischen Welt II Principat vol 21.1. Berlin/New York: De Gruyter. 295-42.

Pearson, BA 1997. The Emergence of the Christian Religion. Harrisburg, Pennsylvania: Trinity Press.

Rowland, C 1982. The Open Heaven. A Study of Apocalyptic in Judaism and Early Christianity. London: SPCK.

Rowland, C 1985. Christian Origins. From Messianic Movement to Christian Religion. Minneapolis: Augsburg Publishing House.

Runia, DT 1986. Philo of Alexandria and Timaeus of Plato. Leiden: Brill.

Runia, DT 2001. Philo of Alexandria. On the Creation of the Cosmos according to Moses. Introduction, Translation and Commentary. Leiden: Brill.

Tobin, VA 1989. Theological Principles of Egyptian Religion. NY/Bern/Frankfort am Main/Berlin: Peter Long. 


$$
\text { http://scriptura.journals.ac.za }
$$

Van Huyssteen, J Wentzel 2006. Alone in the World? Human Uniqueness in Science and Theology. The Gifford lectures, The University of Edinburgh, Spring, 2004. Grand Rapids, Michigan/Cambridge, UK: Willian B Eerdmans Publishing Company.

Wilkinson, R. 1994. Reading Egyptian Art. London: Thames and Hudson. 